\title{
Catalina Andrango-Walker. El Símbolo católico indiano (1598) de Luis Jerónimo de Oré. Saberes coloniales y los problemas de la evangelización en la región andina, Madrid-Frankfurt, Iberoamericana-Vervuert, 2018, 237 págs.
}

El texto de Catalina Andrango-Walker es un libro sobre otro libro, el Símbolo católico indiano del sacerdote franciscano Luis Jerónimo de Oré, que fue publicado por primera y única vez en Lima, en 1598.

El libro de Andrango-Walker aborda la biografía de Oré centrándose en su criollismo, es decir, en aquella controvertida categoría que en el siglo XVI denigraba la naturaleza de quienes nacían o permanecían mucho tiempo en América. Nacido en Huamanga, en el actual Ayacucho, Oré se distancia del término criollo considerándose a sí mismo un hijo de la tierra o un indiano, categoría que explicita el vínculo directo con su tierra natal, del cual Oré se sentía orgulloso.

Oré, como otros intelectuales virreinales, formuló su indianismo a partir de posiciones que hoy, bajo el prisma de demandas étnicas o políticas, nos parecerían antagónicas, pero que en la época eran plenamente compatibles. Un indiano es una persona que, sin ser indígena, se siente conectado con la tierra en que nació pero, al mismo tiempo, se considera heredero de la historia de esa patria lejana que es España. Las Indias son su presente y España su pasado. A medio camino entre dos mundos, como señala la autora, Oré se formó intelectualmente en la Universidad de San Marcos de Lima, donde estudió Teología, pero construyó su experiencia en terreno, en su condición de misionero itinerante.

Oré pasó periodos de su vida en lugares muy disímiles y distantes, más allá del espacio andino. Fuera de Jauja, Cusco y Collaguas, en el actual Perú, y Potosí, en Bolivia, el sacerdote franciscano también estuvo en La Florida, en Norte América, en Concepción, Chile, y también en España. Aquí y allá forjó amistades y rivalidades, siempre defendiendo la humanidad de los indígenas y condenando los abusos que les infligían las autoridades coloniales, aunque sin nunca renunciar al umbral indianista desde el cual escribió. Por ejemplo, Oré no dudó en posicionarse y condenar la ejecución de Atahualpa y el expolio de sus bienes, al mismo tiempo que adhirió a la tesis toledana que planteaba que antes de los incas solo existían behetrías y señores locales y que, en consecuencia, los títulos de la Corona en las Indias eran legítimos.

Oré tradujo su experiencia en terreno en una elaborada crítica de la praxis evangelizadora, identificando en la labor de los curas una prédica superficialy poco comprometida, que privilegiaba la condena de la idolatría por sobre la conversión espiritual de los indígenas. La crítica de Oré es también un juicio político que apunta a la corrupción de los sacerdotes. En medio de frecuentes 
disputas entre el clero secular y el regular, Oré defiende la presencia franciscana en el Nuevo Mundo, destacando la humildad y honestidad de la Orden.

La autora señala que el Símbolo católico de Oré es un libro estructurado en torno a dos ejes temáticamente heterogéneos. El primero consiste en una exposición de la naturaleza de Dios y la historia de Perú; mientras que el segundo está conformado por varios cánticos y rezos en quechua y aimara, en algunas ocasiones glosados en latín o en otras con una introducción en español, cuyo objetivo explícito es la evangelización de los indígenas. El hilo que atraviesa todo el Símbolo, más allá de su orden, es la mística cristiana, que plantea que el conocimiento de Dios es una experiencia sensorial que conmueve los afectos y los corazones. De hecho, el referente directo de Oré es fray Luis de Granada, de cuyo libro Introducción al símbolo de la fe tomó el título para su obra.

Andrango-Walker detecta en el Símbolo una mística indiana, fundada en, al menos, tres aspectos. El primero es la reivindicación de la trascendencia de la existencia del Nuevo Mundo, una verdadera revolución en la historia del Orbe en la perspectiva de Oré. Por medio del Símbolo, Perú queda instalado en el escenario geopolítico de la modernidad, posición que el autor reafirma con una breve descripción de su historia naturaly su población. Un segundo aspecto fundacional en la mística indiana del Símbolo es la abierta proclamación del providencialismo andino, que iguala a los incas con las culturas gentiles europeas, como los griegos y los romanos. Finalmente, la mística que subyace a la obra se basa en la convicción de que las estrategias de predicación del evangelio en el Perú deben ajustarse a un púbico andino. En consecuencia, se trata de un proceso de traducción que debe ir acompañado de una pedagogía pastoral interactiva, que conmueva y deleite, con lágrimas y gemidos, las almas de los indígenas del común, a quienes está dirigido el Símbolo. Por esta razón, para Oré, los mitos, leyendas y tradiciones locales constituyen un medio para acercar el Evangelio a los gentiles del Perú.

En esta línea, Andrango-Walker ofrece un análisis de dos cánticos del Símbolo, evidenciando cómo Oré articuló su pedagogía pastoral integrando los mitos andinos. El primero es un exhorto al sol, la luna y las estrellas, para anunciarles que no son dioses, sino que fueron creadas por Dios. El segundo, en tanto, se centra en la pasión de Cristo. En ambos la autora identifica mecanismos de adaptación y manipulación de las memorias locales, con el expreso fin de establecer la superioridad y veracidad de la fe católica.

Andrango-Walker también sitúa a Oré en la escena intelectual local y peninsular, partiendo por Huamanga y su propia familia. De sus diecisiete hermanos, cinco fueron curas y cuatro se convirtieron en monjas, todos vinculados a la orden franciscana. Según el propio Oré, en las traducciones al quechua de los himnos y rezos presentes en el Símbolo participaron tres de sus hermanos, un círculo intelectual que también influenció al cronista andino Felipe Guaman Poma de Ayala. Otro de los amigos de Oré fue el Inca Garcilaso de la Vega, con quien se reunió en España en 1612. 
A momentos anticipatorio, a momentos retrospectivo, el libro de Catalina Andrango-Walker es una buena guía para entender el contexto pastoral que rodeó la génesis de la obra. Como la misma autora lo plantea, "el Símbolo ofrece otra posibilidad de entender mejor el Perú virreinal de finales del siglo XVI al adentrar al lector a un discurso que anticipa tempranamente las posiciones ideológicas que adoptarán los intelectuales criollos" ( $\mathrm{p}$. 31). Junto con ello, el libro es a companion para introducirse en la vida del propio Jerónimo de Oré. De hecho, la autora cierra su obra con la transcripción de dos documentos, pertenecientes a la colección del Archivo de Indias, que dan a conocer un aspecto poco explorado de la vida de Oré: su desempeño como obispo de la Concepción, en Chile, a fines de 1620.

Con todo, el Símbolo es una unidad textual compleja, tanto por la naturaleza intuitiva que rodea la comprensión de los misterios de la fe en la mística cristiana, como por su condición multilingüe, que demanda múltiples procesos de ajuste, traducción e interpretación. Ambos aspectos aún esperan un estudio en profundidad, de la mano de una edición crítica que explore el rico universo doctrinal y teológico que subyace al Símbolo católico de Oré.

Soledad González Díaz

Centro de Estudios Históricos-CEH Universidad Bernardo O’Higgins 